\title{
Implementation of species protection act for the conservation of Tanimbar corella, Cacatua goffiniana (Roselaar \& Michels, 2004)
}

\author{
TRI HARYOKO ${ }^{1,2, \bullet}$, MARK O'HARA ${ }^{3}$, BERENIKA MIODUSZEWSKA ${ }^{3}$, HARI SUTRISNO ${ }^{2}$, \\ LILIK BUDI PRASETYO ${ }^{4}$, ANI MARDIASTUTI ${ }^{4, \bullet \bullet}$ \\ ${ }^{1}$ Program of Tropical Biodiversity Conservation, Faculty of Forestry and Environment, Institut Pertanian Bogor. J1. Ulin, Lingkar Akademik, IPB \\ University Campus Dramaga, Bogor 16680, West Java, Indonesia. Tel.: +62-251-8621947, Fax.: +62-251-8621947, `email: trih007@ gmail.com \\ ${ }^{2}$ Museum Zoologicum Bogoriense, Research Center for Biology, Indonesian Institute of Sciences. Jl. Raya Jakarta Bogor Km 46, Cibinong, Bogor \\ 16911, West Java, Indonesia \\ ${ }^{3}$ Messerli Research Institute, University of Veterinary Medicine Vienna. Veterinaerplatz 1, 1210 Vienna, Austria \\ ${ }^{4}$ Department of Forest Resources Conservation and Ecotourism, Faculty of Forestry and Environment, Institut Pertanian Bogor. J1. Ulin, Lingkar \\ Akademik, IPB University Campus Dramaga, Bogor 16680, West Java, Indonesia. Tel.: +62-251-8621947, Fax.: +62-251-8621947, \\ • email: ani_mardiastuti@apps.ipb.ac.id
}

Manuscript received: 23 October 2020. Revision accepted: 10 March 2021.

\begin{abstract}
Haryoko T, O'Hara M, Mioduszewska B, Sutrisno H, Prasetyo LB, Mardiastuti A. 2021. Implementation of species protection act for the conservation of Tanimbar corella, Cacatua goffiniana (Roselaar \& Michels, 2004). Biodiversitas 22: 1733-1740. Birds are among the most favored pet animals and are nurtured because of their melodious voice, intelligence, and beautiful feathers. Therefore, these animals are usually traded in both local and international markets. Wild bird trades are dominated by species from the order Passeriformes/songbirds and Psittaciformes/parrots. Furthermore, one of the Psittaciformes groups that are in high demand as a pet is the cockatoos. The Goffin's cockatoo or Tanimbar corella/Cacatua goffiniana (Roselaar \& Michels,2004)is one of seven species of parrots native to Indonesia and has been traded for decades. This endemic bird from the Tanimbar Islands (Maluku Province) has been protected by the Indonesian government since 1990 and has been on the CITES Appendix I since 1992. Therefore, this study aims to review the harvesting of $C$. goffiniana and the effect the bird's protection status has on its trade. It was conducted by investigating the legal trade data for 1981-2018, information on illegal trade, and ex-situ conservation of this species. The review on the trade of $C$. goffiniana was assessed using descriptive analysis. Furthermore, Independent Samples T-Test was used to determine the differences between the number of $C$. goffiniana traded before and after the bird was listed in Appendix I CITES and protected by Indonesia's law. The results showed that the number of exported Cacatua goffiniana for 38 years to 34 countries was 151,684. Furthermore, the United States of America was the largest importer with a total of $118,356 / 78.03 \%$. It was discovered that the number of birds legally exported by Indonesia has decreased dramatically since 1990 because these animals are protected by Indonesian law. Consequently, there was a significant difference between the number traded before and after their designation as protected species. The nonparametric correlation between protection status and Appendix I CITES listing to the number of these animals traded was statistically significant. Finally, existing conservation practices involve efforts to restock the population by means of captive breeding programs. However, as conservation agencies have shown little success in breeding these species, the efforts are not sufficient to fulfill the demand. Therefore, illegal trade is still a major threat to the natural populations.
\end{abstract}

Keywords: Cockatoo, protection, harvesting, trade, conservation

\section{INTRODUCTION}

The main threats to biodiversity conservation are habitat destruction, hunting, and wildlife trade (Nijman and Shepherd 2010; Wilcove et al. 2013). Furthermore, this trade is carried out to satisfy the market demands for food, luxury goods, tourist attraction, medicines, and pet animals (Nijman 2010; Harris et al. 2015). The international illegal wildlife trade earns billions of dollars annually (WilsonWilde 2010), while the legal bird trade and business contribute USD 78.8 million to the national economy of Indonesia within the same period (Jepson et al. 2011).

Wildlife trade has caused a decline in the populations of several species in many countries in Asia, South America, and Africa (Alves et al. 2013; van Balen et al. 2013; Shepherd et al. 2013; Martin 2018), and contributes to the risk of biological invasion (García-Díaz et al. 2017). Furthermore, when this trade is carried out illegally, it leads to the destruction of habitats and the unsustainable exploitation of many species (Ogden and Linacre 2015). Nearly 66 parrot species worldwide are now classified as threatened due to population declines caused by illegal trade (Pires 2012). Moreover, based on the IUCN Red List, 112 of the 398 species of this bird are categorized as Threatened, 55 as Vulnerable, 39 as Endangered, 18 as Critically Endangered, 60 as Near Threatened, while 226 are of Least Concern (Birdlife International 2018). Consequently, regulations have been implemented at the international, national, and local levels to combat this illegal trade. Internationally, wildlife trade is regulated under CITES (Hitchens and Blakeslee 2020). Meanwhile, in Indonesia, the Act of the Republic of Indonesia Number 5 of 1990 and Ministry of Environment and Forestry regulation number P.106/MENLHK/SETJEN/KUM.1/12/2018 have been implemented to protect several flora and fauna species. 
Birds are one of the favorite pet animals due to their color, vocalization, and intelligence. Furthermore, Southeast Asia is a global hotspot for wild bird trade (Harris et al. 2015), while Indonesia is one of the largest pet bird trade centers (Jepson et al. 2011). Parrots including macaw, cockatoos, and lorries are the most popular in commerce, followed by flamingos, eagles, toucans, and songbirds.

In 2018, the Natural Resources and Conservation Agency (BKSDA) Maluku rescued about 1,135 birds, of which $96 \%$ were parrots. Also, the Maluku Islands are targets for illegal trade of the wild members of this bird because 34 out of 82 of its species in Indonesia are found in those Islands (Setiyani and Ahmadi 2020). Meanwhile, according to Tamalene et al (2019), a total of 327 members of the four species of this bird in Ternate Island, North Maluku Province were illegally traded between 2013 and 2015. Parrots are notable pet birds because of their colorful plumage, lifelong capacity for learning, vocalization ability, and charismatic character (White et al. 2011).

Cacatua goffiniana (Roselaar \& Michels,2004) is one of the parrots that are in high demand as a pet and are valued for their small size and curious behavior. Furthermore, this species is endemic and has been traded for several decades. Studies on $C$. goffiniana have been carried out in their natural habitats and captivity, concerning the bird's cognition and behavior in the laboratory (Auersperg et al. 2012, 2013a,b, 2014; Rössler et al. 2020), genetic identity (Zein et al. 2017), natural foraging, and socio-ecology (Mioduszewska et al. 2019, O'Hara et al. 2019). However, specific research and detailed harvesting data on the bird are still extremely limited. Therefore, this study aims to review the data on the harvesting of $C$. goffiniana for legal trade, illegal poaching, and investigate ex-situ conservation and captive breeding. It also aims to analyze the difference in the trade of this bird after its establishment as a protected species by Indonesian law and after it was listed in the CITES Appendix I.

\section{MATERIALS AND METHODS}

\section{Data}

Data on the legal trade of C. goffiniana from 1981-2018 was obtained from the CITES Trade Database (UNEP-WCMC 2019) and downloaded on May 15, 2020. The categories used to obtain the data are year range (1981-2018), exporting country (Indonesia), importing countries (all countries), and all sources, purposes, and trade terms. CITES classified these terms into four types namely live, bodies, feather, and specimens. Also, the sources of the birds were divided into six source codes namely captive (C), wild (W), unspecified (U), born in captivity $(\mathrm{F})$, pre-convention $(\mathrm{O})$, and confiscation (I). Lastly, the birds were traded for seven purposes including to be kept in zoos, and for personal, commercial, scientific, circus, captive breeding, and unspecific purposes.

Data collection on the illegal trade of $C$. goffiniana between 2009 and 2020, and its utilization by zoos and captive breeders was conducted in 2018-2020. Furthermore, the data were obtained from the WCS-IP, Natural Resources and Conservation Agency, and various media reports. Finally, data on the conservation efforts of ex-situ to preserve this bird was obtained from the Indonesian Zoos and Aquariums Association (IZAA), while breeder data were obtained through inspection of several breeders in West, Central, and East Java, and Bali.

\section{Analysis}

The review on the trade of $C$. goffiniana was assessed using descriptive analysis. Furthermore, data were tested for normality using the Kolmogorov-Smirnov Test, while Independent Samples T-Test was used to determine the differences between the number of $C$. goffiniana traded before and after the bird was listed on Table S1 and protected by Indonesia's law. Univariate Analysis of Variance was used to determine the effect of protection and CITES listing on the number of trades conducted. Finally, analyses were performed using IBM SPSS Statistic 22 software (IBM Corp. Released 2013).

\section{RESULTS AND DISCUSSION}

\section{Results}

The total number of legally traded $C$. goffiniana reported to CITES from 1981-2018 was 151,681, from 209 events. Meanwhile, the number from 1981-1990 was 141,441 , while only 10,240 were traded after the species was established as a protected bird by Indonesian law in 1990. Since 2004 there have been no more legal exports of this bird by Indonesia. There are differences in the amount reported by exporters and importers because some trading transactions were only reported by the exporting or importing country. The number of legally traded $C$. goffiniana reported to CITES from 1981-2018 is presented in Figure 1 and Table S1.

According to CITES Trade Database, information on the purpose and source of most of the traded birds is not clearly stated. Consequently, over the years, the designation of $C$. goffiniana trade was highest for not specified $(58.6 \%)$, followed by commercial $(41.4 \%)$, personal $(0.002 \%)$, and zoo $(0.001 \%)$. The traded birds were obtained primarily from wild-caught members $(6.4 \%)$, followed by captive breeding $(0.032 \%)$, and confiscations $(0.011 \%)$.

A total of 141,949 individual records $(93.6 \%)$ did not include information on their source. These records were primarily those where the exporting country (Indonesia) was the source. Therefore, it is likely that those birds originated from the wild because breeders in Indonesia have not developed the capacity to export in such large quantities (see details in Table 1).

Cacatua goffiniana from Indonesia was imported by 34 countries. Furthermore, Figure 2 presents the top ten countries importing the bird by the total number of individuals $(>0.5 \%)$. It shows that the United States of America was the largest importer with a total of 118,356 (78.0\%). Meanwhile, the remaining 24 countries (others) imported only 3,667 individuals $(2.4 \%)$ combined. A detailed list of importing countries and numbers of individuals is presented in Table S2. 
The Indonesian government encourages various parties to preserve $C$. goffiniana through ex-situ conservation in zoos, safari parks, eco-parks, and captive breedings. Based on data from the IZAA, 10 of the 51 member conservation agencies are in possession of only 46 individuals of this bird. Furthermore, only six breeders are definitively known to have tried to breed the bird in captivity, thus the number available for breeding is low, as only 56 males, 36 females, and 4 unknown sex individuals are in captivity (breakdown in Table 2). This amount is not sufficient to produce a second generation that could supply the local or international legal trade markets.

To date, C. goffiniana has not been bred successfully by the ex-situ conservation agencies or breeders in order to increase the population available for trade. There are also no records of the number of hatchlings produced by these bodies. However, market demand still exists for the species, thus supply is made via illegal trade and captive breeding outside of Indonesia. Illegal trade and direct capture from the wild population still occur even though this species is protected and included in Appendix I of
CITES. Therefore, in this study, after monitoring the media, NGOs, and tabulating confiscations by Natural Resources and Conservation Agency (BKSDA), it was recorded that 237 individuals were illegally traded between 2009 and 2020 (see Table 3).

Table 1. Purposes, sources, and trade term for international trade of Cacatua goffiniana

\begin{tabular}{llrr}
\hline Type & Detail & $\begin{array}{r}\text { Number of } \\
\text { individuals }\end{array}$ & $\begin{array}{r}\text { Percentage } \\
(\%)\end{array}$ \\
\hline Purposes & Commercial & 62,756 & 41.400 \\
& Personal & 3 & 0.002 \\
& Zoo & 2 & 0.001 \\
& Unspecific & 88,900 & 58.600 \\
\multirow{5}{*}{ Sources } & Breeding & 20 & 0.013 \\
& Unknown & 141,949 & 93.600 \\
& Captive Breeding & 48 & 0.032 \\
& Confiscations & 17 & 0.011 \\
Trade term & Wild & 9,667 & 6.373 \\
& Live & 151,639 & 99.900 \\
& Bodies & 42 & 0.028 \\
\hline
\end{tabular}



Figure 1. The trend of Cacatua goffiniana trade from Indonesia 1981-2018



Figure 2. Top importer countries of Cacatua goffiniana came from Indonesia 1981-2018 
Table 2. Ex-situ conservation agency which has a collection of Cacatua goffiniana

\begin{tabular}{|c|c|c|c|c|}
\hline Ex-situ conservation agency & Male & Female & Unknown & Total \\
\hline \multicolumn{5}{|l|}{ Zoo } \\
\hline Safari Park II Indonesia & 8 & 10 & & 18 \\
\hline Surabaya Zoo & 2 & 2 & 3 & 7 \\
\hline Ragunan Zoo & 2 & 2 & 2 & 6 \\
\hline Sinka Island Park, Singkawang & & & 3 & 3 \\
\hline Pancuranmas Educational Ecotourism Park & 1 & 1 & 1 & 3 \\
\hline Bandung Zoo & 1 & 1 & & 2 \\
\hline Jurug Solo Zoo & 1 & 1 & & 2 \\
\hline Citra Bird Park & 1 & 1 & & 2 \\
\hline Bali Zoo & & & 2 & 2 \\
\hline Cikembulan Animal Park & & & 1 & 1 \\
\hline Total & 16 & 18 & 12 & 46 \\
\hline \multicolumn{5}{|l|}{ Breeder by location (number) } \\
\hline West Java (1) & 1 & 1 & & 2 \\
\hline East Java (1) & 47 & 27 & 3 & 77 \\
\hline Central Java (3) & 7 & 7 & 1 & 15 \\
\hline Bali (1) & 1 & 1 & & 2 \\
\hline Total & 56 & 36 & 4 & 96 \\
\hline
\end{tabular}

Table 3. Illegal trade of Cacatua goffiniana 2009-2020

\begin{tabular}{llccl}
\hline Year & \multicolumn{1}{c}{ Data level } & Location of data source & Number & Data sources \\
\hline 2009 & Local trade (Smuggling) & Banten & 1 & WCS-IP \\
2009 & Local trade & East Java & 3 & (Viva 2019) \\
2010 & Pet & Banten & 1 & WCS-IP \\
2013 & Local trade (online) & Jakarta & 2 & WCS-IP \\
2013 & Pet & West Java & 1 & WCS-IP \\
2016 & International trade (smuggling) & Yogyakarta & 4 & WCS-IP \\
2017 & Local trade & Central Java & 3 & WCS-IP \\
2018 & Local trade (online) & East Java & 2 & WCS-IP \\
2018 & Local trade & Jakarta & 3 & WCS-IP \\
2018 & Breeding & East Java & 78 & WCS-IP \\
2018 & Local trade & Maluku & 61 & Natural Resources and Conservation \\
& & & & Agency (BKSDA) Maluku \\
2019 & Local trade (Smuggling) & East Java & 50 & WCS-IP \\
2019 & Local trade (online) & South Sulawesi & 13 & WCS-IP \\
2020 & Local trade & Maluku & 15 & Natural Resources and Conservation \\
& & & & Agency (BKSDA) Maluku \\
Total & & & 237 & \\
\hline
\end{tabular}

From the independent samples t-test, it was ascertained that there were significant differences in the number of $C$. goffiniana traded internationally before and after the bird was protected by Indonesian law and listed in Appendix I CITES in 1992 (Sig. 2-tailed $0.000<0.05$ ). Furthermore, the Univariate Analysis of Variance determined that the significant decrease in the number of birds exported by the country was affected by protection (sig $0.011<0.05$ ) and CITES listing ( $\operatorname{sig} 0.000<0.05)$.

\section{Discussion}

The results suggest that Indonesian legislation (Act of the Republic of Indonesia No. 5 of 1990) concerning the conservation of living resources and their ecosystems have likely reduced the number of legally traded $C$. goffiniana in the international market. Under Article 21, it is prohibited for anyone to capture, own, keep, trade, or export protected animals from one place in Indonesia to another or even abroad. Therefore, protected animals could only be used when permission is obtained from the government.

The classification of $C$. goffiniana by CITES as an animal in Appendix I limits its use through regulation and restrictions. Moreover, CITES Appendix I includes the most endangered plant and animal species and all those threatened by trade. The body also prohibits international trade of specimens for commercial purposes. However, exclusions could be made for the purpose of scientific research. Captive-bred animals on Appendix I are considered as Appendix II, with associated requirements (Article VII CITES exemptions and other special provisions relating to trade). The requirement is that the scientific authority of the exporting country need to demonstrate scientifically that the export of animals would 
have no adverse or detrimental impacts on the natural population (CITES 2018).

The total number of $C$. goffiniana exported between 1981 and 2018 was 151,681 individuals. This number is higher than that of $C$. galerita (Sulphur-crested Cockatoo) exported within the same period, which was only 12,798 (Rachmatika et al. 2020). The number of $C$. goffiniana legally exported by Indonesia from 1981-1990 reached 141,441 individuals (around 14,144 individuals per year). This amount was more than that predicted by Birdlife International (2018), which is that bird trade in the 1980s was around 10,000 birds per year.

The international trade of $C$. goffiniana was primarily for commercial purposes, such as making the bird available for purchase as a pet $(41.4 \%)$, although the purposes of 88,900 individuals were not explained in detail. Finally, only a small number was traded for personal (3 individuals), zoo ( 2 individuals), and captive breeding (20 individuals) purposes.

In the natural habitat $C$. goffiniana are highly social, innovative, opportunistic feeding generalists that feed on a large diversity of items in the forest and on agricultural grounds (O'Hara et al. 2019; Mioduszewska et al. 2019. Furthermore, studies under controlled laboratory conditions by Auersperg et al. (2014), showed that this bird rivals the intelligence of small children, monkeys, and crows in several cognitive domains. Thus, while $C$. goffiniana are popular for their inquisitive nature, ability to quickly form social bonds, their intelligence, and ecology, they are best not kept in captivity, unless adequate housing, enrichment and living conditions are provided. For opportunistic generalists, this species (as is the case for most cockatoos) have a great destructive ability and might be extremely vocal.

For the purposes of trade, CITES Trade Database reported that 20 individualas of $C$. goffiniana was sold to South Africa in 2003 for breeding. Moreover, from online searches, it was discovered in this study that several countries are also breeding this bird in captivity. Auersperg et al. (2014) for instance, obtained 14 individuals for behavioral research from CITES accredited breeders in Germany. The United States of America and Germany are the countries that imported the largest number of $C$. goffiniana from Indonesia within the period of 1981-2018, with a total of 118,356 and 8,354 individuals respectively.

Parrots are one of the birds commonly used as pets in the USA. Thus, the country was also the largest importer of Neotropical parrots at around 50,000-150,000 per year from 1980-1990 (Pires 2012). Finally, Rachmatika et al. (2020) reported that the United State of America was also the largest importer of $C$. galerita from Indonesia from 1981-2018.

The results of this study showed that the dominant source of traded birds was either wild-caught or unknown sources, as only $0.032 \%$ was reported to come from captive breeding. Furthermore, it showed that even a small proportion of captive breeding poses a serious threat to the wild population for these birds, and when demand is high, the supply would come from poaching in the natural habitat. Thus, the number of individuals traded from captive breeding was lower than the general estimate by ProFauna (2009), which proposed that overall wildlife trade involves mostly (95\%) wild individuals and 5\% from captive breeding.

Cacatua goffiniana is near threatened, and extinction could occur because it is an endemic bird with a limited natural distribution of only around $9200 \mathrm{~km}^{2}$ in the Tanimbar Islands. Furthermore, only small feral and reproducing population has been reported in Puerto Rico and Singapore (Birdlife International 2018).

Indonesian captive breeding companies and zoos have shown limited interest in the captive breeding of $C$. goffiniana because this parrot species is less attractive than others that have vibrant colors. This is true as only ten zoos out of 51 members of IZAA have about 1-2 pairs of this bird with a total of 46 individuals, while six breeding companies have 96 in total.

Cacatua goffiniana have white feathers with a salmonpink lore and light yellow suffusion under the tail and flight feathers, as well as dark brown iris in males and reddishbrown in female (Roselaar and Michels 2004). Furthermore, they are much smaller in size $(30-32 \mathrm{~cm})$ than other cockatoos $(45-60 \mathrm{~cm})$ and weigh about around $300 \mathrm{~g}$. These traits are in contrast to other cockatoos which are larger with pronounced yellow crest (Cacatua galerita and Cacatua sulphurea) or are colored pale salmon-pink with a deep salmon-pink crest in their young (Cacatua mollucensis) (Eaton et al. 2016).

The Indonesian government provides opportunities for the captive breeding of birds through the Act of the Republic of Indonesia No. 5 of 1990 Article 36 paragraph 1 and Government Regulation No. 8, 1999, concerning the use of wild plants and animal species. Based on these regulations, the offspring of captive protected wildlife could be used for trade purposes when it is the second or subsequent generation.

According to the data reported by CITES, only $48 C$. goffiniana sourced from captive breeds were exported within the period of 1987-1989 and 2003 (Table 1). Therefore, greater capacity within Indonesia to develop captive breeding, including additional conservation measures are needed for this endemic bird of the Tanimbar Islands. This study also discovered that the unavailability of these birds to legally supply markets is one of the reasons for the illegal trade in Indonesia.

Between 2009-2020, 237 C. goffiniana were illegally exported and confiscated from various sources. This number is different from that shown in the study by Setiyani and Ahmadi (2020) which found that in 2018, no C. goffiniana was illegally traded in Maluku. Burung Indonesia (2018) reported that in 2005, 10,560 individuals of this species were illegally poached and traded from this island. Meanwhile, based on the data recorded at CITES (2018), within that same year, there were no legal exports of the bird from Indonesia.

Indonesia is an archipelago with many islands, thus, illegal activities sometimes go undetected by the police and law enforcement. The borders are also not well controlled, and economic and the livelihood limitations of local people make it easier for these crimes to occur (Wilson-Wilde 
2010). C. goffiniana uses agricultural land as foraging area, thus the bird could easily be trapped in the field.

Parrots generally are demand internationally, and the supply is largely satisfied by international CITES accredited breeders. Therefore, domestic demand for this bird is the largest driving force behind illegal trade (Pires 2012). The low record of confiscated C. goffiniana could be attributed to several factors, including effective law enforcement, the community switching to trade in songbirds, and the understanding that this bird is a protected species. Setiyani and Ahmadi (2020) reported that BKSDA Maluku conducted routine patrols and monitored targeted source area to prevent any illegal parrot harvesting.

Some studies reported that songbird species are traded in Indonesia (Shepherd 2011; Shepherd et al. 2016; Harris et al. 2015; Chng et al. 2016; Harris et al. 2017; Chng et al. 2018a,b; Nijman et al. 2018). Furthermore, Kristianto and Jepson (2011), estimated that Bali supplied 160,000 Orange-headed thrush Zoothera citrina, a prestigious songbird competition species in Indonesia within 20082009.

Rare and endangered species are targets of collectors and pets. Moreover, illegal wildlife trade could greatly damage the efforts of developing countries in managing their natural resources (Rosen and Smith 2010) and is thought to contribute to the threatened status of 66 parrot species worldwide (Gastañaga et al. 2011). Due to $C$. goffiniana being endemic to the Tanimbar Islands, the bird has the potential to act as a key species for developing ecotourism in those regions. Thus, subsequent illegal trade of this species including other Tanimbar's endemic birds would greatly harm future tourism development.

\section{Conservation implications}

The threat of decline in plant and wildlife populations is due to a variety of reasons, such as pollution, deforestation, destruction of natural habitats, and climate change. Furthermore, wildlife trade also contributes greatly to this problem through uncontrolled hunting and harvesting. The trade of $C$. goffiniana has multiple implications for the species, human livelihoods, biodiversity, and governance. Therefore, bird and habitat protection need to be a part of a comprehensive approach to achieving sustainable use of biodiversity, community welfare and conservation. Handling confiscated birds from illegal trade requires high costs. Also, before the species could be returned to the wild, they need to be rehabilitated, and this costs much and bears the risk of spreading diseases to the natural populations.

The Conservation Act of the Republic of Indonesia No. 5 of 1990, Article 5, states that conservation should be carried through three primary activities, namely protection, preservation, and sustainable use. Protection status and being listed in Appendix I by CITES influenced the decline in the trade of $C$. goffiniana. However, the local and international demand for this species cannot be satisfied legally from Indonesia, therefore, illegal trade continues. The survival of $C$. goffiniana populations depends mainly on its protection, natural habitat, engagement with local communities to reduce poaching of the bird, and the success of captive breeding.

The establishment of the Tanimbar Wildlife Sanctuary has preserved the natural habitat of the $C$. goffiniana in Yamdena Island, however, since these birds often use agricultural land as one of their foraging areas, they move outside their natural habitats. Therefore, the local community needs to be educated and involved in protecting this endemic bird species to prevent over-harvesting. The establishment of captive breeding for $C$. goffiniana on Tanimbar and the development of ecotourism would provide jobs and increased income, therefore, local communities could enjoy sustainable benefits due to the presence of this species on the Islands.

\section{ACKNOWLEDGEMENTS}

The authors are grateful to the Research Center for Biology-LIPI, Ministry of Environment and Forestry of Republic Indonesia through the Natural Resources and Conservation Agency (BKSDA), East Java, and Maluku, for granting permission for this study to be carried out. The authors are also grateful to WCS-IP, Indonesian Zoos and Aquariums Association (IZAA) for providing the data. Finally, the authors are grateful to Mohammad Irham for providing comments and ideas to improve the manuscript. This research was funded by the DIPA 2019 of the Natural Resources and Conservation Agency East Java, DIPA 2020 of the Ecology and Conservation of Endangered Species of Research Center for Biology-LIPI, and Deputy of Research and Development of the Ministry of Research and Technology-National Research and Innovation in accordance with the Agreement on Assignment of Research Implementation in 2020 Number 1/E1/KP.PTNBH/2020 March 18, 2020, and Amendments to the Research Contract Number 1/AMD/E1.KP.PTNBH/2020 May 11, 2020. All authors contributed equally to this work. This research was also funded in part, by the Austrian Science Fund (FWF): J4169-B29 'Cognitive ecology of Goffin's cockatoos (Cacatua goffiniana)' awarded to MO. All authors contributed equally to this work.

\section{REFERENCES}

Alves RRN, Lima DFJR, Araujo HFP. 2013. The live bird trade in Brazil and its conservation implications: An overview. Bird Conserv Int 23 (1): 53-65. DOI: 10.1017/S095927091200010X.

Auersperg AMI, Szabo B, von Bayern AMP, Kacelnik A. 2012. Spontaneous innovation in tool manufacture and use in a Goffin's cockatoo. Curr Biol 22 (21): R903-R904. DOI: 10.1016/j.cub.2012.09.002.

Auersperg AMI, Laumer IB, Bugnyar T. 2013a. Goffin cockatoos wait for qualitative and quantitative gains but prefer "better" to "more." Biol Lett 9 (3): 20121092. DOI: 10.1098/rsbl.2012.1092

Auersperg AMI, Kacelnik A, von Bayern AMP. 2013b. Explorative learning and functional inferences on a five-step means-means-end problem in Goffin's cockatoos (Cacatua goffini). PloS ONE 8 (7): e68979. DOI: 10.1371/journal.pone.0068979

Auersperg AMI, Szabo B, von Bayern AMP, Bugnyar T. 2014. Object permanence in the Goffin cockatoo (Cacatua goffini). J Comp Psychol 128 (1): 88-98. DOI: 10.1037/a0033272. 
Birdlife International. 2018. Cacatua goffiniana. The IUCN Red List of Threatened Species 2018: e. T22 684800 A13 191 5554. DOI 10.2305/ IUCN.UK.2018-2. RL TS. T 22684 800A1 31915554. Downloaded on 31 July 2019.

Burung Indonesia. 2018. Kakatua Tanimbar: Diburu dan dianggap hama https://www.burung.org/2018/02/06/kakatua-tanimbar-diburu-dandianggap-hama. [November 20, 2019].

Chng SCL, Guciano M, Eaton JA. 2016. In the market for extinction: Sukahaji, Bandung, Java, Indonesia. BirdingASIA 26: 22-28.

Chng SCL, Krishnasamy K, Eaton JA. 2018a. In the market for extinction The cage birds trade in Bali. Forktail 34: 35-41.

Chng SCL, Shepherd CR, Eaton JA. 2018b. In the market for extinction Birds for sale at selected outlets in Sumatra. TRAFFIC Bulletin 30 (1): $15-22$.

CITES. 2018. Trade database \& dashboard. www.cites.org. Accessed on September 24, 2018.

Eaton JA, van Balen B, Brickle NW, Rheindt FE. 2016. Birds of the Indonesian Archipelago. Greater Sundas and Wallacea. Lynx Editions, Barcelona.

García-Díaz P, Ross JV, Woolnough AP, Cassey P. 2017. The illegal wildlife trade is a likely source of alien species. Conserv Lett 10 (6): 690-698. DOI: $10.1111 /$ conl.12301

Gastañaga M, MacLeod R, Hennessey B, Núñez JU, Puse E, Arrascue A, Hoyos J, Chambi WM, Vasquez J, Engblom G. 2011. A study of the parrot trade in Peru and the potential importance of internal trade for threatened species. Bird Conserv Int 21 (1): 76-85. DOI: 10.1017/S0959270910000249.

Harris JBC, Green JMH, Prawiradilaga DM, Giam X, Giyanto, Hikmatullah D, Putra CA, Wilcove DS. 2015. Using market data and expert opinion to identify overexploited species in the wild bird trade. Biol Conserv 187: 51-60. DOI: 10.1016/j.biocon.2015.04.009.

Harris JBC, Morgan WT, Fangyuan H, Yong DL, Adeney JM, Lee TM, Marthy W, Prawiradilaga DM, Sekercioglu CH, Suyadi, Winarni N, Wilcove DS. 2017. Measuring the impact of the pet trade on Indonesian Birds. Conserv Biol 31 (2): 394-405. DOI 10.1111/cobi.12729.

Hitchens RT, Blakeslee AMH. 2020. Trends in illegal wildlife trade: analyzing personal baggage seizure data in the Pacific Northwest. PLOS ONE 15 (6): 1-22. DOI: 10.1371/journal.pone.0234197.

IBM Corp. Released. 2013. IBM SPSS Statistics for Windows Version 22.0. Armonk, NY: IBM Corp..

Jepson P, Ladle RJ, Sujatnika. 2011. Assessing market-based conservation governance approaches: A socio-economic profile of Indonesian markets for wild birds. Oryx 45 (4): 482-491. DOI: 10.1017/S003060531100038X.

Kristianto I, Jepson P. 2011. Harvesting orange-headed thrush Zoothera citrina chicks in Bali, Indonesia: Magnitude, practices and $\begin{array}{lllll}\text { sustainability. } & \text { Oryx } & 45 & \text { (4): } & \text { 492-499. }\end{array}$ DOI:10.1017/S0030605310001481.

Martin RO. 2018. The wild bird trade and African parrots: Past, present and future challenges. Ostrich 89 (2): 139-143. DOI: 10.2989/00306525.2017.1397787.

Mioduszewska BM, O’Hara MC, Haryoko T, Auersperg AMI, Huber L, Prawiradilaga DM. 2019. Notes on ecology of wild Goffin's cockatoo in the late dry season with emphasis on feeding ecology. Treubia 45 (12): 85-102. DOI: 10.14203/treubia.v45i0.3706.

Nijman V. 2010. An overview of international wildlife trade from Southeast Asia. Biodivers Conserv 19 (4): 1101-1114. DOI: 10.1007/s10531-009-9758-4.

Nijman V, Shepherd CR. 2010. The role of Asia in the global trade in CITES II-listed poison arrow frogs: Hopping from Kazakhstan to Lebanon to Thailand and beyond. Biodivers Conserv 19 (7): 19631970. DOI: 10. 1007/s10531-010-9814-0.

Nijman V, Langgeng A, Birot H, Imron MA. 2018. Trade, captive breeding and the imminent extinction of a songbird. Glob Ecol Conserv 15: e00425. DOI: 10.1016/j.gecco.2018.e00425.

O’Hara M, Mioduszewska B, Haryoko T, Prawiradilaga DM, Huber L, Auersperg A. 2019. Extraction without tooling around: The first comprehensive description of the foraging and socio-ecology of wild Goffin's cockatoos (Cacatua goffiniana). Behaviour 156 (5-8): 661690. DOI: $10.1163 / 1568539 X-00003523$.

Ogden R, Linacre A. 2015. Wildlife forensic science: A review of genetic geographic origin assignment. Forensic Sci Int Genet 18 (9): 152-159. DOI: $10.1016 /$ j.fsigen.2015.02.008.

Pires SP. 2012. The illegal parrot trade: A literature review. Glob Crime 13 (3): 176-190. DOI: 10.1080/17440572.2012.700180.

ProFauna. 2009. Wildlife trade survey on the bird markets in java. ProFauna's Report. ProFauna Indonesia, Malang, Indonesia. www.profauna.org. [Indonesian]

Rachmatika R, Suparno, Prijono, SN, Ari H, Sari AP, Maharani S. 2020. Export of Sulphur-crested Cockatoo (Cacatua galerita Latham, 1790) and that Captive Breeding at Research Center of Biology Breeding Facility-LIPI. Jurnal Biologi Indonesia 16 (1): 47-56. DOI:10.47349/jbi/16012020/47 [Indonesian]

Roselaar C, Michels JP. 2004. Systematic notes on Asian birds. 48. Nomenclatural chaos untangled, resulting in the naming of the formally undescribed Cacatua species from the Tanimbar Islands, Indonesia (Psittaciformes: Cacatuidae). Zool Verh Leiden 350 (2004): 183-196.

Rosen GE, Smith KF. 2010. Summarizing the evidence on the international trade in illegal wildlife. EcoHealth 7 (1): 24-32. DOI: 10.1007/s10393-010-0317-y

Rössler T, Mioduszewska B, O’Hara M, Huber L, Prawiradilaga DM, Auersperg AMI. 2020. Using an innovation arena to compare wildcaught and laboratory Goffin's cockatoos. Sci Rep 10 (1): 1-12. DOI: 10.1038/s41598-020-65223-6.

Setiyani AD, Ahmadi MA. 2020. An overview of illegal parrot trade in Maluku and North Maluku provinces. For Soc 4 (1): 48-60. DOI: $10.24259 /$ fs.v4i1.7316.

Shepherd CR. 2011. Observations on trade in Laughing thrushes (Garrulax spp.) in North Sumatra, Indonesia. Bird Conserv Int 21 (1): 86-91. DOI: 10.1017/S0959270910000274.

Shepherd CR, Shepherd LA, Foley KE. 2013. Straw-headed Bulbul Pycnonotus zeylanicus: Legal protection and enforcement action in Malaysia. BirdingASIA 19 (1): 92-94.

Shepherd CR, Eaton JA, Chng SCL. 2016. Nothing to laugh about - The ongoing illegal trade in Laughing thrushes (Garrulax species) in the bird markets of Java, Indonesia. Bird Conserv Int 26 (4): 524-530. DOI: 10.1017/ S095 9270916000320.

Tamalene MN, Hasan S, Kartika. 2019. Local knowledge and community behavior in the exploitation of parrots in surrounding area of Aketajawe Lolobata National Park. Biosfer 12 (1): 24-33. DOI: 10.21009/biosferjpb.v12n1.24-33

UNEP-WCMC. 2019. Full CITES Trade Database Download. CITES Secretariat. www. trade.cites.org.

Van Balen, SB, Eaton JA, Rheindt FE. 2013. Biology, taxonomy and conservation status of the Short-tailed Green Magpie Cissa [t.] thalassina from Java. Bird Conserv Int 23 (1): 91-109. DOI:10.1017/S09592709110003609.

Viva. 2019. Wildlife trading network continues to be hunted. www.viva.co.id/arsip/148612. Acceses November 17, 2019 [Indonesian]

White NE, Phillips MJ, Gilbert MTP, Núñez AA, Willerslev E, Mawson PR, Spencer PBS, Bunce M. 2011. The evolutionary history of cockatoos (Aves: Psittaciformes: Cacatuidae). Mol Phyl Evol 59 (3): 615-622. DOI: 10.1016/j.ympev.2011.03.011.

Wilcove DS, Giam X, Edwards DP, Fisher B, Koh LP. 2013. Navjot's nightmare revisited: Logging, agriculture, and biodiversity in Southeast Asia. Trends Ecol Evol 28 (9): 531-540. DOI: 10.1016/j.tree.2013.04.005.

Wilson-Wilde L. 2010. Wildlife crime: A global problem. Forensic Sci Med Pathol 6 (3): 221-222. DOI: 10.1007/s12024-010-9167-8.

Zein MSA, Haryoko T, Fitriana YS, Sulistyadi E, Prawiradilaga DM. 2017. Application of molecular DNA and phenotypic study for reintroduction programme of Cockatoos). Jurnal Biologi Indonesia 13 (1): 157-169. [Indonesian] 
Table S1. The number of legally traded Cacatua goffiniana reported to CITES from 1981-2018

\begin{tabular}{|c|c|c|c|}
\hline \multirow{2}{*}{ Year } & \multicolumn{3}{|c|}{ Quantity (individuals) } \\
\hline & Importer reported & Exporter reported & Total \\
\hline 1981 & 545 & 1710 & 2255 \\
\hline 1982 & 4487 & 5953 & 10440 \\
\hline 1983 & 6326 & 14181 & 20507 \\
\hline 1984 & 5707 & 10729 & 16426 \\
\hline 1985 & 6205 & 7314 & 13519 \\
\hline 1986 & 6495 & 10039 & 16514 \\
\hline 1987 & 5479 & 9522 & 15001 \\
\hline 1988 & 7301 & 11817 & 19118 \\
\hline 1989 & 6010 & 12348 & 18356 \\
\hline 1990 & 4965 & 4340 & 9305 \\
\hline 1991 & 3985 & 7246 & 8794 \\
\hline 1992 & 526 & 898 & 1424 \\
\hline 1993 & 0 & 0 & 0 \\
\hline 1994 & 0 & 0 & 0 \\
\hline 1995 & 0 & 0 & 0 \\
\hline 1996 & 0 & 0 & 0 \\
\hline 1997 & 0 & 0 & 0 \\
\hline 1998 & 1 & 0 & 1 \\
\hline 1999 & 1 & 0 & 1 \\
\hline 2000 & 0 & 0 & 0 \\
\hline 2001 & 0 & 0 & 0 \\
\hline 2002 & 0 & 0 & 0 \\
\hline 2003 & 20 & 0 & 20 \\
\hline 2004 & 0 & 0 & 0 \\
\hline 2005 & 0 & 0 & 0 \\
\hline 2006 & 0 & 0 & 0 \\
\hline 2007 & 0 & 0 & 0 \\
\hline 2008 & 0 & 0 & 0 \\
\hline 2009 & 0 & 0 & 0 \\
\hline 2010 & 0 & 0 & 0 \\
\hline 2011 & 0 & 0 & 0 \\
\hline 2012 & 0 & 0 & 0 \\
\hline 2013 & 0 & 0 & 0 \\
\hline 2014 & 0 & 0 & 0 \\
\hline 2015 & 0 & 0 & 0 \\
\hline 2016 & 0 & 0 & 0 \\
\hline 2017 & 0 & 0 & 0 \\
\hline 2018 & 0 & 0 & 0 \\
\hline & 58053 & 96097 & 151681 \\
\hline
\end{tabular}

Table S2. A detailed list of importing Countries of Cockatoo reported to CITES from 1981-2018

\begin{tabular}{|c|c|c|}
\hline Importing countries & $\begin{array}{l}\text { Number of } \\
\text { individuals }\end{array}$ & $\begin{array}{c}\text { Percentage } \\
(\%)\end{array}$ \\
\hline United States of America & 118356 & 78.030 \\
\hline Germany & 8354 & 5.508 \\
\hline Singapore & 7249 & 4.779 \\
\hline Taiwan & 4017 & 2.648 \\
\hline Malaysia & 3693 & 2.435 \\
\hline France & 2146 & 1.415 \\
\hline Japan & 1332 & 0.878 \\
\hline Denmark & 1123 & 0.740 \\
\hline United Kingdom of Great Britain & 977 & 0.644 \\
\hline Hongkong & 767 & 0.506 \\
\hline Italy & 550 & 0.363 \\
\hline Austria & 524 & 0.345 \\
\hline Australia & 513 & 0.338 \\
\hline Switzerland & 384 & 0.253 \\
\hline Botswana & 364 & 0.240 \\
\hline Spain & 265 & 0.175 \\
\hline Thailand & 214 & 0.141 \\
\hline South Africa & 194 & 0.128 \\
\hline China & 140 & 0.092 \\
\hline unknown & 124 & 0.082 \\
\hline Sweden & 110 & 0.073 \\
\hline Republic of Korea & 90 & 0.059 \\
\hline Belgium & 75 & 0.049 \\
\hline Greece & 37 & 0.024 \\
\hline Bangladesh & 32 & 0.021 \\
\hline Philippines & 11 & 0.007 \\
\hline Yugoslavia & 11 & 0.007 \\
\hline Pakistan & 10 & 0.007 \\
\hline Guatemala & 6 & 0.004 \\
\hline Nepal & 5 & 0.003 \\
\hline Saudi Arabia & 4 & 0.003 \\
\hline Deutsche Demokratische republik & 2 & 0.001 \\
\hline Czechoslovakia & 1 & 0.001 \\
\hline \multirow[t]{2}{*}{ Paraguay } & 1 & 0.001 \\
\hline & 151681 & 100 \\
\hline
\end{tabular}

